MISES: Revista Interdisciplinar de Filosofia, Direito e Economia ISSN 2318-0811

Volume IV, Número 1 (Edição 7) Janeiro-Junho 2016: 183-201

\title{
A Liberdade Antes do Liberalismo: O Caso de Francisco Suárez
}

\author{
Paulo Emílio Vauthier Borges de Macedo*
}

\begin{abstract}
Resumo: Francisco Suárez foi um dos mais importantes teólogos da Escolástica Espanhola e, no século XX, uma corrente crescente de juristas tem reconhecido a sua contribuição para a origem do Direito Internacional. Contudo, a sua Filosofia do Direito tem sido relegada, apesar de o autor ter exposto ideias tão revolucionárias que foram proibidas na Inglaterra, em França e até mesmo na Espanha. O tempo amaldiçoou e esqueceu Francisco Suárez porque ele defendeu o Liberalismo quase um século antes dos britânicos. Direitos humanos, o contrato social e limites ao poder do Estado (e mesmo ao do Papa) eram conceitos audaciosos demais para um católico espanhol do final do século XVI.
\end{abstract}

Palavras-Chave: Suárez. Liberalismo. Escolástica. Direitos subjetivos. Tiranicídio.

\section{Liberty before Liberalism: The Case of Francisco Suárez}

\begin{abstract}
Francisco Suárez was one of the most important Theologians of the Spanish Scholasticism and, in the $20^{\text {th }}$ century, a growing strand of lawyers has acknowledged his contributions to the origin of International Law. However, his Legal Philosophy has been relegated, despite the fact that he had expounded ideas so revolutionary that they were forbidden in England, France and ultimately even Spain. Time has cursed and forgotten Francisco Suárez because he supported Classical Liberalism almost a century before the Britons. Human rights, the social contract and limits to the State's (and even to the Pope's) power were concepts too bold for a late Sixteenth-century Catholic Spaniard.
\end{abstract}

Keywords: Suárez. Classical liberalism. Scholasticism. Subjective rights. Tyrannicide.

Classificação JEL: B10, K00, Z19.

\footnotetext{
* Paulo Emílio Vauthier Borges de Macedo Professor adjunto da UERJ, vice coordenador do PPGDir e autor dos livros Guerra e Cooperação Internacional, Hugo Grócio e o Direito: o jurista da guerra e da paz e de O nascimento do direito internacional. As referências às obras de Tomás de Aquino e de Francisco Suárez seguem a notação tradicional (sigla, parte ou livro, questão ou capítulo, artigo e as suas divisões internas ou numeração). O autor agradece a importante contribuição do CNPq para este texto.

E-mail: borgesmacedo@hotmail.com
} 


\section{I - Prolegômenos À guisA DE INTRODUÇÃO}

A Filosofia Jurídica Moderna foi injusta em relação a Francisco Suárez (1548-1617). O pensamento de Francisco Suárez influenciou sobremaneira a teologia católica e protestante, mas ele foi relegado entre os filósofos e os juristas. Quando muito, o teólogo granadino é lembrado como a fonte de um François Glisson. Sua maior obra jurídica-política, o De Legibus ac Deo Legislatore, acabou tão somente por ganhar pó nas estantes das bibliotecas. Já o seu segundo maior texto nesse gênero, a $D e-$ fensio Fidei Catholicae adversus anglicanae sectae errores, foi, até mesmo, proibido em França e chegou a ser queimado na Inglaterra, tamanha a polêmica que causou. Isso deveria ser um indicativo das ideias que esse escritor defende. Somente na segunda metade do século XIX, quando se descobre que Hugo Grócio (1583-1645) não detém, com exclusividade, a paternidade do direito internacional, os textos jurídicos e políticos de Suárez são revitalizados. Percebe-se, então, que Suárez não é apenas um grande teólogo - um dos maiores do chamado "século de ouro" da Espanha e o mais importante da segunda vaga da escolástica espanhola -, mas também antecipou teses jurídico-políticas bastante modernas como o contrato social, a origem popular do poder e a doutrina do tiranicídio. Além disso, o escritor apresenta uma noção de direito natural que se ajusta às mudanças históricas, o que salva o jusnaturalismo suareziano de uma das mais contundentes críticas que o positivismo profere contra o direito natural moderno. Tão original é o pensamento do autor que alguns comentaristas o consideram a fonte de uma modernidade alternativa. Ademais, ele desenvolveu uma concepção sofisticada e original de jus gentium.

Francisco Suárez nasce em Granada, em 5 de janeiro de 1548 e morre em Lisboa, em 24 de setembro de 1617. Procede de uma família católica e nobre, que prestava serviços à Coroa desde os tempos da Reconquista. Estuda em Salamanca durante dois anos até solicitar o ingresso na recém fundada Companhia de Jesus - uma ordem intelectual desde as suas origens -, em 1564. Apesar da junta de examinadores reconhecer uma profunda vocação eclesiástica, ela reprova Suárez porque o considera muito burro. O jovem parte para Valladolid e pede a intercessão do provincial de Castilha, Juan Suárez (que não possui maiores relações com Francisco, além do sobrenome). Todos os conselheiros emitem pareceres desfavoráveis à entrada, mas o provincial se apieda e entrega a Francisco Suárez uma carta de recomendação destinada ao reitor. O jovem finalmente consegue o noviciado, mas é admitido na qualidade de "Indiferente", isto é, caso não demonstrasse aptidão para o estudo, iria se tornar um simples irmão coadjutor, uma condição aquém de sua fidalguia e formação'.

Infelizmente, Suárez não se destaca nos estudos e revela uma dificuldade considerável com matérias abstratas. Então, procura manter-se calado e evita debates públicos sobre temas em que os demais alunos buscam se exibir. Seu mutismo lhe rende o apelido de "boi mudo", numa clara alusão irônica a Santo Tomás de Aquino, o primeiro a exibir essa alcunha. Seus professores designam colegas para ajudá-lo nas provas, mas isso causa apenas maior mortificação ao jovem. Convencido de sua vocação como irmão de serviço, Suárez acode ao padre diretor Martim Gutierrez e, com abnegação, pede trabalhos braçais e afirma contentar-se em ser apenas servidor dos sábios.

Mais uma vez, a humildade de Suárez desperta piedade. Gutierrez responde que o jovem deve perseverar nos estudos, que a aparente inutilidade dos esforços somente aumenta o mérito. E acrescenta que iria rezar

\footnotetext{
${ }^{1}$ Todas as referências sobre a vida de Suárez são retiradas da clássica biografia de SCORRAILLE, Raoul de, S.I. François Suárez de la Compagnie de Jésus. D'après ses lettres, ses autres écrits inédits et un grand nombre de documents nouveaux. Paris: P. Lethielleux, 1912. 2 tomos.
} 
durante toda a noite e pedir ao Nosso Senhor Jesus Cristo para lhe conceder o dom da sabedoria. As orações parecem surtir efeito, e Suárez, de maneira gradual, torna-se um aluno melhor. Termina, em abril de 1570, os cursos de Teologia com certa notoriedade de sabedoria entre colegas e professores. Anos depois, em 1607, o Papa Paulo V (1552-1621) refere-se a Suárez como Doctor Eximius et Pius. Também neste caso, o boi mudo mugiu².

Tradicionalmente, define-se a primeira matriz liberal - a jusnaturalista britânica pela presença dos seguintes três elementos: o contrato social para legitimar a criação do Estado, a defesa de um governo limitado e a ideia de direitos naturais, em oposição ao jusnaturalismo antigo que só concebia a existência de uma lei natural. Essas três noções autorizaram a John Locke (1632-1704) o epíteto de um dos pais fundadores do liberalismo. Já a ausência de apenas um desses elementos seria suficiente para descartar um Thomas Hobbes (1588-1679) e um Jean-Jacques Rousseau (1712-1778) como protoliberais.

Porém, não há dúvidas de que essa leitura consiste numa categorização ex post. Nenhum dos três grandes contratualistas escrevia com o firme propósito de se tornar o pai do liberalismo. Isso se tornou especialmente claro quando, em Cambridge, Peter Laslett demonstrou que Locke havia se debruçado sobre os Dois Tratados do Governo Civil desde 1681, momento em que o partido Whig - ao qual o autor pertencia - planejava recorrer à violência política. Até então, sempre se havia pensado que o trabalho de Locke havia sido escrito para justificar a Revolução Inglesa de 1688-1689. Mas os dois tratados não eram a consolidação da Revolução Gloriosa; antes expressavam parte do debate e das tomadas de posicionamento dos atores da revolução. Eram textos que possuíam engajamento no contexto político e social da época. A filosofia

\footnotetext{
${ }^{2}$ A metáfora irônica pertence a CORDEIRO, Valério. O Padre Francisco Suárez (Doutor Exímio). Porto: Livraria Magalhães e Moniz, 1918, p. 16.
}

política de Locke não se encontrava distante da ação política, numa torre de marfim, como se costumava pensar que a Filosofia (bem como a teoria política) deveria ser $^{3}$.

Ninguém escreve para uma plateia universal, mas para os debates da época em que se insere. E é por isso que fomos injustos com Suárez. Ele não seria lido no mundo anglo-saxão que despontava, por causa da proibição aos seus livros. E, por ser jesuíta, foi também esquecido no mundo ibérico, que já anunciava a decadência: o Marquês de Pombal (16991782) mandou construir um mundo em frente ao túmulo de Suárez para impedir a visitação. $\mathrm{O}$ autor foi esquecido.

Francisco Suárez se insere na tradição cultural escolástica. E foi um dos maiores. Ele sintetiza todo o pensamento escolástico de forma tão competente que Jacques-Bénigne Bossuet (1627-1704) afirmou "en lui on voit toute l'École". Mas ele não é só mais um tomista. Tomás de Aquino (1225-1274) não presenciou os acontecimentos, nem antecipou as discussões que se imporiam sobre as gerações espanholas dos séculos XVI e XVII: o descobrimento da América, o direito dos índios, os limites ao direito de evangelização e a emergência de um controverso direito - defendido pelos Monarcomacci na Itália e, em Espanha, por Juan de Mariana (1536-1624) - sobre desobediência civil. Por mais impactantes que tenham sido estes eventos, eles não poderiam invalidar a essência do tomismo. Isso era inegável até para os mais vulgares teólogos católicos; todavia, para os mais capazes, o tomismo precisava ser atualizado.

\section{II - Os Direitos Subjetivos}

A tarefa de atualização tornou Suárez um tomista muito pouco ortodoxo. Na Idade

${ }^{3}$ Cf. POCOCK, J. G. A. Quentin Skinner: a história da política e a política da história. Trad. Patrick Wuillaume e Guilherme Pereira das Neves. Topoi, v. 13, n. 25, jul/ dez 2012, p. 195. 
Média, as obras de Metafísica não se apartavam dos cânones estabelecidos por Aristóteles (384 a.C.-322 a.C.). Étienne Gilson (1884-1978) conclui que as Disputationes Metaphysicae constituem, em verdade, um tratado filosófico moderno, "pois o autor deliberadamente se apartou de toda a sujeição ao texto da Metafísica de Aristóteles (...). Pautar-se pelos objetos mesmos da Metafísica, e não mais pela letra de Aristóteles (...) é escrever sobre Metafísica em vez de escrever sobre Aristóteles" ${ }^{\prime 4}$.

A Metafísica suareziana descobriu o individual. Na Gnosiologia tradicional, o universal é "objeto do conhecimento direto e, portanto, é captado na simples apreensão que engendra o conceito". Há uma correspondência direta entre o conceito e aquilo que existe: o universal possui existência real. Os nossos conceitos são de universais, e esses universais existem. Já a coisa " ut singularis só é conhecida indiretamente ou por uma reflexão que, por meio da espécie inteligível universal própria da cognição direta, converte a mesma em imagens da fantasia" ${ }^{5}$. Atinge-se o individual por meio de um mecanismo complexo chamado de "individuação"; trata-se de um processo de reunião, num mesmo objeto, de diversos universais. Dessa maneira, v.g., define-se o individual "Sócrates" pelo conjunto de seus atributos universais: Homem, Mortal, Sexo Masculino, etc. Por esse motivo, os individuais consistem em substâncias compostas.

\footnotetext{
4 “(...) car leur auteur s'est délibérément affranchi de toute sujétion au texte de la Métaphysique d'Aristote (...). Se régler ainsi sur les objets mêmes de la métaphysique, et non plus sur la lettre d'Aristote (...) c'était s'engager à écrire sur la métaphysique au lieu d'écrire sur Aristote." (GILSON, Étienne. L'Être et L'Essence. 2. ed. Paris: J. Vrin, 1962, p. 145).

5 “(...) objeto del conocimiento directo y, por tanto, se capta en la simple aprehensión que engendra el concepto (...). “(...) la cosa ut singularis sólo es conocida indirectamente o por una reflexión que, a través de la especie inteligible universal propria de la cognición directa, convierte hacia las imágenes de la fantasía (...)." (LARRAINZAR, Carlos. Una introducción a Francisco Suárez. Pamplona: Universidade de Navarra, 1977, p. 124).
}

Porém, Suárez não pensa assim. Ao usar o termo "espécie", o autor quis designar uma realidade em si mesma. Diverso do exposto acima, para o autor, o "nosso entendimento conhece diretamente os singulares materiais sem a reflexão [dos fantasmas produzidos em nossa mente]". E somente depois o "entendimento conhece como um conceito próprio, abstraindo dos singulares e não se preocupando com eles" ${ }^{\prime \prime}$. O processo de cognição percorre o caminho inverso do que Santo Tomás preconizava: primeiro, conhece-se o singular, para depois abstrair deles o universal.

Esse axioma cognitivo irá ressoar na concepção suareziana de Direito Natural. Pensadores escolásticos redigiam um Tratado sobre as Leis e outro sobre a Justiça e o Direito, conforme disposto na Suma Teológica de Aquino. Um versa sobre os diferentes tipos de Lei (Lei Natural, Lei Civil, etc.) que correspondem, na verdade, à própria Lei Eterna de Deus em diferentes domínios de existência, o mesmo universal. E o outro trabalho tem por objeto a justiça, o ius, a coisa justa nas relações humanas, a justiça de uma determinada situação, uma coisa concreta e singular.

Mas Suárez escreve tão somente um grande e abrangente "Tratado das Leis e de Deus Legislador". Isso é muito significativo. A Lei Natural do autor confere direitos naturais a indivíduos, uma característica bastante moderna. Por isso, uma das acepções de ius, conforme o autor, é uma certa "faculdade moral que cada um tem em relação ao que é seu, ou ao que lhe é devido; na verdade, assim se diz que o dono de uma coisa tem direito sobre ela e que o trabalhador tem direito ao pagamento, razão pela qual se diz

\footnotetext{
6 "Intellectus noster cognoscit directe singularia materialia absque reflexione". "Intellectus cognoscit proprio conceptu universalia, abstrahendo a singularibus seu non curando de illis". (SUÁREZ, Francisco (S. I.). Commentaria una cum quaestionibus in libros Aristotelis "De Anima". Madrid: Labor Sociedad de estudios y publicaciones, 1978, IV, 3, 7 e IV, 3, 11).
} 
que merece a sua recompensa"7. Trata-se da concepção moderna de direito subjetivo.

Suárez chegou a esse conceito ao reinterpretar autores bastante antigos, como não poderia ser diferente. Num sentido mais estrito de justiça, como uma virtude específica, não como a virtude em geral, o tomismo tradicional retomava a divisão aristotélica da justiça em legal, comutativa e distributiva. A justiça legal trata das relações entre todas as pessoas que existem na cidade. $\mathrm{O}$ direito (ius) objeto dessa justiça corresponde às ações e aos bens dos súditos que devem conformar-se às leis. Ao Estado, exige-se apenas que legisle com vistas ao bem comum. Já a justiça distributiva ocorre entre pessoas desiguais, entre superior e inferior, entre o Estado e os súditos. O direito objeto dessa justiça é a distribuição dos bens públicos da polis. A coisa que se deve a alguém não pertence propriamente a esse alguém, mas apenas de forma relativa, segundo a sua capacidade ou dignidade. Trata-se de um direito num sentido menos rigoroso, mais fraco, bastante afastado da noção de domínio.

Por último, o que hoje se denomina de direito subjetivo corresponde à re-interpretação de Suárez da justiça comutativa. Essa justiça opera nas relações entre os iguais, dos súditos entre si. A regra é a igualdade das trocas. Este é o direito por excelência, porque reflete a definição mais corrente de justiça ("dar a cada um o seu"). Suárez não emprega a expressão "justiça comutativa", mas retoma a tradicional frase romana e insere nela uma sutil alteração: o pronome "seu" torna-se uma espécie de "faculdade moral": "certo poder ou faculdade moral que cada um tem sobre o que é seu e sobre aquilo que lhe devem" $"$.

\footnotetext{
7 "(...) facultas quaedam moralis, quam unusquisque habet vel circa rem suam vel ad rem sibi debitam; sic enim dominus rei dicitur habere ius in re et operarius dicitur habere ius ad stipendium ratione cuius dicitur dignus mercede sua" (SUÁREZ, Francisco. Tratactus de legibus, ac Deo Legislatore in decem Librus distributus. Venetiis: Sebastianum Coleti. 1740 [doravante DL] I, 2, 5).

8 "(...) ius vocari facultas quaedam moralis, quam unusquisque habet vel circa rem suam vela d rem sibi debitam" (DL. I, 2, 5).
}

Com isso, ele consegue deslocar o foco desse conceito do objeto para o sujeito. Os clássicos centravam essa definição não no sujeito titular da coisa devida, mas na própria coisa devida. Era, pois, a situação, a coisa, que era "justa". Antes, a definição mais corriqueira referia-se a algo bastante distinto.

A ciência jurídica dos clássicos, para estabelecer o direito de alguém (jus suum cuique), não parte do indivíduo, mas objetivamente da massa dos bens sociais a dividir: o direito de alguém é um quociente. O direito não é, pois, um "atributo" do indivíduo, isoladamente considerado, mas uma coisa, uma coisa objetiva ("coisa incorpórea"), uma quantidade delimitada de prerrogativas ou de encargos. Ele não é um "poder" para realizar determinada atividade (circular, manifestar sua opinião, cultivar a terra), mas - e eis uma nuança essencial - uma zona de poder, um setor de ação delimitado por outros setores atribuídos a outros associados [de uma determinada sociedade] (grifo no original) ${ }^{9}$.

Até então, o direito de alguém correspondia ao reflexo do conjunto de deveres imposto a todo o restante da comunidade. $\mathrm{O}$ indivíduo podia reivindicar não o seu direito, mas o cumprimento, por parte de outrem, de uma obrigação que lhe era devida. Suárez passa a centrar a definição de ius no sujeito titular da coisa. Assim, o objeto da justiça comutativa torna-se uma "faculdade justa". Essa faculdade pertence ao sujeito, como se emanasse dele próprio de modo independente da existência de uma lei - esta considerada uma tábua de

\footnotetext{
9 "La science juridique des classiques, pour établir le droit de chacun (jus suum cuique), ne part pas de l'individu, mais objectivement de la masse des biens sociaux à partager: le droit de chacun, c'est un quotient. Le droit n'est donc pas 'l'attribut' de l'individu, isolément considéré, mais une chose, une chose objective ('chose incorporelle'), une quantité délimitée de prérogatives ou de charges. Il n'est pas 'pouvoir' d'accomplir telle activité (circuler - dire son opinion-cultiver l aterre), mais - voici la nuance essentielle - zone de pouvoir, secteur d'action délimité par rapport à d'autres secteurs attribués à d'autres associés." (VILLEY, Michel. Leçons d'Histoire de la Philosophie du Droit. Paris: Dalloz, 1962, p. 160).
} 
obrigações -, que dispusesse sobre aquilo que os outros devem a esse sujeito.

Uma das maiores diferenças entre o jusnaturalismo medieval e o moderno reside na concepção de direito subjetivo, o poder de agir conferido a um indivíduo. A lei natural, para os medievos, representa um ordenamento, um conjunto de deveres que se impõe aos homens. Ela designa tarefas e atividades de caráter obrigatório. Em certo sentido, a lei natural medieval opõe-se à liberdade do ser humano. No máximo, ela estabelece o limite externo dessa liberdade; corresponde aos deveres do indivíduo em relação à comunidade.

O direito natural moderno, ao contrário, confere ao homem um determinado poder em face de toda a sociedade. O direito subjetivo é sinônimo de poder. Trata-se de uma liberdade que o indivíduo possui mesmo que outro ordenamento jurídico (mormente o positivo) não the atribua. A existência desse direito independe do conjunto de leis; sua origem e fundamento repousam no próprio homem, não em algo externo. Ao descobrir o singular, em sua Metafísica, Suárez valoriza o indivíduo como criador e destinatário da lei.

De um modo geral, a noção de direito subjetivo distingue o jusnaturalismo medieval do moderno e constitui o fundamento para o que pode ser chamado hoje de "direitos humanos". Os direitos subjetivos existem para empoderar os indivíduos contra o arbítrio dos seus soberanos. Outrossim, limitam não só o poder do Príncipe, mas de toda a sociedade são direitos contramajoritários: uma margem de liberdade no qual o indivíduo pode perseguir o seu próprio destino sem a interferência de toda a comunidade. E Suárez foi o primeiro a enunciar isso.

\section{III - A Teoria do Estado}

Francisco Suárez revela toda a sua modernidade, de maneira bastante contundente, na teoria política. Embora o seu objeto de estudo ainda fosse a Teologia, o autor se mostra um politólogo de primeira grandeza. De fato, ele defende teses que a filosofia protestante de um século depois apenas muito lentamente iria conseguir desenvolver. Ele trata de assuntos como a origem popular do poder, as relações entre a Igreja e o Estado e o direito de desobediência civil. Comparados à profundidade desses temas, Suárez influenciou pouco as gerações seguintes, e os comentários a essa parte de sua obra são escassos.

A teoria do Estado de Suárez aparece no livro III do De Legibus, bem como na Defensio Fidei. A história desta obra é bastante conhecida. Desde 1600, o cardeal Roberto Berlarmino (1542-1621) empenhava-se na restauração católica da Inglaterra e depositava esperanças na figura de Jaime I (1566-1625), então Jaime VI da Escócia. Mas os acontecimentos da Conjuração da Pólvora de 1605 resultaram em severos atritos entre o rei e os católicos, em especial os jesuítas. O provincial Garnet foi até mesmo executado por ordem real. A resposta do monarca não se encerrou com o castigo exemplar. Em 1606, votam-se leis persecutórias com base em um juramento de fidelidade ${ }^{10}$.

Tratava-se do terceiro juramento que um monarca inglês impunha a seus súditos católicos desde a Reforma. O primeiro, imposto por Henrique VIII (1491-1547) somente aos clérigos que podiam votar no Parlamento, recebeu uma nova formulação por Isabel I (1533-1603) que o prescreveu a todos, à exceção das autoridades civis. Jaime I amplia de forma considerável tanto o texto como o conteúdo. Os católicos ingleses deveriam declarar, e Deus seria testemunha, que ele era o rei legítimo e supremo senhor do reino. $\mathrm{O}$ juramento ainda acrescenta que nenhuma potência estrangeira, em especial o papa, poderia interferir no seu governo, e nada nem nin-

\footnotetext{
${ }^{10}$ Cf. CARRILLO PRIETO, Ignácio. Cuestiones jurídicopolíticas en Francisco Suárez. México: UNAM, Instituto de Investigaciones Jurídicas, 1977, p. 58.
} 
guém teria autoridade para condenar os seus atos. Restaria aos súditos, apenas, o dever de obediência mesmo em face de uma sentença de excomunhão ${ }^{11}$.

De modo aparente, o juramento possuía tão somente um caráter político e não poderia atrair a atenção da Igreja Católica. O monarca desejara garantir a sua supremacia e segurança pessoal ao consolidar a soberania absoluta sobre o Estado inglês. Tratava-se, em princípio, de uma manifestação do absolutismo corrente à época. Cabe observar que os últimos juramentos políticos haviam ocorrido na Alta Idade Média para sacralizar os deveres mútuos que uniam os senhores e os seus vassalos. Nessa época, não havia necessidade de seduzir o povo; este seguia, por necessidade ou instinto, os seus dirigentes. A opinião da massa popular pouco interessava. Contudo, os tempos mudaram, e fazia-se necessário apelar para a consciência individual, o que, até então, constituía um domínio reservado de um poder estrangeiro: a Igreja. Por esse motivo, o juramento de fidelidade política afetou também as relações entre a Igreja e o Estado $^{12}$.

A tese absolutista de Jaime I mostrava-se um verdadeiro compêndio de toda a tradição política protestante. Por causa do voluntarismo nominalista, o protestantismo exaltava a onipotência dos soberanos, e o rei estava persuadido da sua superioridade.

Acreditava de boa fé ser um teólogo genial que trazia a verdade aos ingleses deso-

\footnotetext{
${ }^{11}$ Cf. Terceira Fórmula de Juramento Arbitrada e Defendida pelo rei Jacobus I. In: SUÁREZ, Francisco. De Iuramento Fidelitatis. Documentación Fundamental. Elaborado bajo da dirección de Luciano Pereña. Madrid: Consejo Superior Superior de Investigaciones Cientificas, Instituto Francisco de Vitória, 1978, p. 2224. (Corpus Hispanorum de Pace, v. XIX).

${ }^{12}$ Cf. ELORDUY, Eleutério, S. J. La soberanía popular segun Francisco Suárez. In: SUÁREZ, Francisco. Principatus Politicus o la Soberania Popular. Elaborado bajo da dirección de Luciano Pereña. Madrid: Consejo Superior de Investigaciones Cientificas, 1965 (Corpus Hispanorum de Pace, v. II).
}

rientados. Jaime I considerava-se o primeiro teólogo da Europa. Proclamava que havia sido pessoalmente eleito por Deus para governar o seu povo, investido de seus poderes diretamente por Deus e que só era responsável perante Deus ${ }^{13}$.

Jaime I defendia, pois, a origem divina do direito dos reis. Por mais estranho que possa parecer, eram os protestantes que advogavam esta tese. Faziam uma interpretação muito literal do "non est potestas nisi a Deo" do apóstolo Paulo. Os católicos, desde Francisco de Vitória, exaltavam a origem popular da soberania. Em verdade, esta teoria integrava a interpretação tradicional do tomismo. Já no século XIII, o pontífice Inocêncio IV enunciava, em termos explícitos que, enquanto o poder do papa provém de Deus - em virtude da doação feita pelo próprio Jesus Cristo a São Pedro -, o do imperador vem do povo ${ }^{14}$.

A afirmação de Inocêncio IV (1195-1254) parece, além de constatar o fundamento popular da autoridade, enaltecer o poder papal. Mas ela foi proferida em outros tempos, quando a noção de monismo imperial ainda pairava sobre as cabeças da cristandade. E, como se verá nas palavras de Suárez, uma variante desse monismo atribuía o título de imperador - e, portanto, senhor de todos os cristãos - ao papa.

Todavia, são os próprios católicos que iriam reconhecer uma limitação à autoridade

13 "Creía de buena fe ser un teólogo genial que traía la verdad a los ingleses desorientados. Jacobo I se consideraba el primer teólogo de Europa. Proclamaba que había sido personalmente elegido por Dios para gobernar a su pueblo, investido de sus poderes directamente por Dios y que sólo era responsable ante Dios." (PEREÑN, Luciano. Perspectiva Historica. In: SUÁREZ, Francisco. De Iuramento Fidelitatis. Estudio Preliminar. Conciencia y Política. Elaborado bajo da dirección de Luciano Pereña. Madrid: Consejo Superior Superior de Investigaciones Cientificas, Escuela Española de la Paz, 1979, p. 16. [Corpus Hispanorum de Pace, v. XVIII]).

${ }^{14}$ Cf. MERÊA, Paulo. Suárez, Jurista. O problema da origem do poder civil. Estudos de Filosofia Jurídica e de História das Doutrinas Políticas. Lisboa: Imprensa Nacional-Casa da Moeda, 2004, p. 119. 
do Sumo Pontífice. O cardeal Belarmino, em 1568, antes mesmo da controvérsia com Jaime I, formulou a doutrina do poder indireto, segundo a qual ao papa se reconhecia a ingerência em assuntos temporais sempre que o reclamassem as conveniências espirituais da Igreja. Ela não concedia o poder temporal ao chefe da Igreja, mas permitia que, em defesa da fé, se poderia, até mesmo, depor os príncipes. Essa solução coincidia com a dos defensores mais moderados do papado; porém, uma vez que não enaltecia o poder pontifical como a doutrina do poder direto, escandalizou, de modo passageiro, a Santa Sé e Gregório XIII (1502-1585). Ainda assim, essa teoria encontrava-se mais consentânea com as condições políticas da época, e o livro de Belarmino foi retirado do Index e reabilitado perante a opinião católica ${ }^{15}$.

Dessa feita, em conformidade com a ingerência reduzida dos novos tempos, a resposta papal ao juramento de fidelidade foi uma simples condenação: num breve, Paulo $\mathrm{V}$ declara sua ilicitude. Jaime I replica com o tratado Apologia pro Iuramento Fidelitatis. Belarmino escreve uma primeira Responsio. O rei, por sua vez, ordena uma reimpressão da Apologia, precedida por um Prefatio Monitoria. Belarmino, então, deseja encerrar a polêmica com uma segunda Responsio ${ }^{16}$.

Nesse contexto, começa a se gestionar na Igreja Católica para que Francisco Suárez interviesse em auxílio a Belarmino. A Reforma havia desferido seu mais poderoso golpe, então a Igreja recorre ao seu teólogo mais importante da época. Suárez aceita sob a condição de haver garantias papais à doutrina que iria expor. De posse dessa certeza, embora seu espírito fosse avesso às controvérsias, aceita, docilmente, seu encargo. Todavia, em vez de redigir uma obra de polêmica, o Doutor Exímio e Pio eleva a discussão e escreve um tratado científico de mais de oitocentas páginas.

\footnotetext{
${ }^{15}$ Cf. MERÊA, Paulo. Suárez, Jurista. Op. Cit., p. 125.

${ }^{16}$ Cf. CARRILLO PRIETO, Ignácio. Op. Cit., p. 58.
}

O rei Jaime I não se atreveu a responder a Defensio Fidei de Suárez. Pareceu-lhe mais cômodo ordenar aos doutores de Oxford para que rechaçassem Suárez e Belarmino num ato público. Além disso, mandou queimar o livro em Londres e proibiu sua leitura em toda a Inglaterra, sob severas penas. Também em França a obra foi queimada, no pátio do Parlamento, por causa da doutrina do tiranicídio. Como se tratava de um reino católico, o Conselho de Luís XIII (1601-1643) prestou satisfações ao papa; no entanto, para não melindrar o Parlamento, conservou-se a proibição ao livro por tempo suficiente até tornar Suárez um autor mal quisto ${ }^{17}$.

\section{IV - A Origem do Poder}

Em teoria política, Francisco Suárez inova em relação ao tomismo tradicional. Esse tema não é tratado de forma perfunctória; o cuidado que o autor dispensa torna o mesmo um problema central. Suárez já havia abordado essa questão, de modo um tanto incipiente, num trabalho de juventude, De Opere Sex Dierum. Pode, pois, afirmar-se que a teoria política foi o tema mais recorrente da vida do jurista de Coimbra. Contudo, o autor não é um politólogo, e seu pensamento político ocorre sempre em função da Teologia.

Portanto, não deve causar estranheza o fato de que a primeira questão que Suárez se propõe, no primeiro capítulo do livro III do De Legibus, seja se os homens têm poder, bem como legitimidade, para legislar. O problema político primordial, para o teólogo granadino, reside no binômio obediência-liberdade: Deus concedeu ou não poder de mando aos homens (ou somente a algum homem em especial) sobre outros homens? Em vista da igualdade de todos os homens, baseada na paternidade divina, como foi acontecer de um homem

\footnotetext{
${ }^{17}$ Cf. ELORDUY, Eleutério, S. J. La soberanía popular segun Francisco Suárez. Op. Cit., pp. XXV-XXX.
} 
tornar-se anteposto a outro? Trata-se de uma questão que remonta a certa interpretação do bispo de Hipona a qual nega, ao Estado, um fundamento no direito natural. Santo Agostinho (354-430), ao transcrever uma passagem do Gênesis, afirma que Deus criou o homem para que dominasse os peixes do mar, as aves do céu, os animais da terra, mas não para que dominasse o seu semelhante. A partir disso, criou-se toda uma corrente de escritores que inferiram o caráter antinatural do poder; sua origem seria o pecado e a corrupção humana ${ }^{18}$.

Essa não é a posição de Suárez. O autor parte da concepção aristotélica de homem como um animal social. E, nesta qualidade, o homem só poderia dispensar o poder político se vivesse só, ou apenas no seio de sua família, mas a sociedade é natural. E "se não existisse nenhuma forma de poder, cada qual agiria de acordo com o seu interesse particular, sendo de considerar que o interesse particular não coincide necessariamente com o bem comum, e até muitas vezes se lhe opõe $\mathrm{e}^{\prime 19}$. Mesmo uma sociedade de anjos pressupõe algum poder de mando, a fim de que haja ordem no agrupamento. O princípio diretivo do poder revela-se natural; apenas a sua porção coercitiva se deve à recalcitrância humana e ao pecado.

Cabe observar que a palavra "sociedade" se mostra, por si, ambígua. Suárez distingue, como também Santo Tomás, a sociedade perfeita ou civil da imperfeita ou doméstica. A família corresponde à sociedade "mais natural" ou "puramente natural" e resulta das relações entre marido e mulher, pais e filhos, e, até mesmo, escravos e senhores. Ela consiste na sociedade natural por excelência, depende imediatamente do instinto natural inerente ao homem. Por isso, a família - embora

\footnotetext{
18 Cf. CAlafATE, Pedro. A filosofia política em Francisco Suárez. In: (coord.). História do Pensamento Filosófico Português. Lisboa: Caminho, 2001. v. II, p. 576.

${ }^{19}$ CALAFATE, Pedro. A filosofia política em Francisco Suárez. Op. Cit., p. 577.
}

sem o cotejo de algumas instituições como a escravidão e o serviço doméstico, as quais se desenvolveram depois do pecado original já existia no estado de inocência. Entretanto, essa primeira comunidade humana chama-se imperfeita em relação à comunidade política, pois não se basta a si mesma. Nela, os homens não podem satisfazer todos os seus interesses e aspirações. Mesmo a satisfação das necessidades naturais, como a procriação, encontram-se bastante limitadas ${ }^{20}$.

Existe, em Suárez, assim como nos escritores políticos modernos, um momento anterior à formação do Estado que o autor denomina de "estado de inocência". O jurista português Diogo Freitas do Amaral promove uma comparação interessante entre este e o estado de natureza hobbesiano e salienta três semelhanças: a liberdade natural, a ausência de poder político e a necessidade de um ato voluntário para a constituição do estado civil $^{21}$. Há, no entanto, uma diferença fundamental: Suárez está preocupado com a salvação das almas, não com a legitimação do poder político. O estado de inocência suareziano desempenha uma função bastante diversa da do estado de natureza hobbesiano. O estado de inocência não constitui uma situação histórica, ou um momento ideal, anterior ao Estado, mas um estado que antecede o pecado original. E a expressão não se contrapõe a "estado civil", como o estado de natureza, mas a "estado de corrupção". O estado de inocên-

\footnotetext{
${ }^{20}$ Cf. DL. III, 1, 3.
}

${ }^{21}$ Cf. AMARAL, Diogo Freitas do. Francisco Suárez e Thomas Hobbes: uma comparação instrutiva. Estado e Direito. Revista Luso-Espanhola de Direito Público, $1^{\circ}$ semestre 1994, n. 13, p. 13. Embora este texto discorde da correspondência entre os dois termos, parece possível que o próprio Hobbes tivesse desejado fazer uma analogia com as categorias políticas escolásticas. É conhecida a fina ironia do filósofo de Malmesbury. Também as alusões que esse autor faz à Bíblia, como o monstro Leviatã, e à Teologia são diversas. Importa ressaltar que, embora o estado de natureza não cesse com a graça divina propriamente, ele finda com outra manifestação também divina, mas de um "deus mortal", o Estado. 
cia representa um tempo idílico, no qual os homens viviam tal como os animais: apenas para satisfazer os instintos básicos. Ele precede tanto o pecado original, como a posterior redenção por meio da infusão da graça divina. Não há Estado, porque não há poder coercitivo, porque não há pecado. Além disso, trata-se de um estado social. Em Suárez, nunca houve um momento pré-social, no qual os homens vivessem como indivíduos isolados. O homem nasce e, por sua própria essência, vive com seus semelhantes.

No estado de inocência, o homem realizava a sua sociabilidade apenas na família. Após a corrupção, agrega-se à família o trabalho escravo e a servidão. Há, portanto, três relações: a do marido e da mulher, a dos pais e dos filhos e a dos senhores e dos escravos. As duas primeiras correspondem a necessidades naturais: a procriação e a sobrevivência e a educação da prole. Com o pecado, acrescenta-se o trabalho escravo e o servil para auxiliar na própria economia doméstica. Dessa forma, o pecado em si mesmo nada faz para incrementar as relações sociais além dos limites da sociedade familiar.

No entanto, a família não contém em si mesma todos os serviços e ofícios necessários para a vida humana. Tampouco permite ao homem buscar aquela sua finalidade própria e racional: conhecer a Deus. É preciso que diversas famílias se reúnam em, ao menos, uma cidade ou numa agremiação ainda maior, um reino. Ademais, se todas as famílias estivessem divididas, poderia conservar-se apenas a paz entre os homens, mas não se poderia nem rechaçar nem punir as injustiças de forma ordenada ${ }^{22}$.

Por esse motivo, a comunidade política e perfeita também decorre de uma necessidade natural, ainda que exclusiva do ser racional. Mesmo que os homens tivessem permanecido no estado de inocência, não deixariam de agrupar-se em comunidades perfeitas, mas não utilizariam o poder coercitivo. Em outras

\footnotetext{
${ }^{22}$ Cf. DL. III, 1, 3.
}

palavras, o Estado é uma prescrição de direito natural ${ }^{23}$.

Até o momento, Suárez permanece fiel ao legado aristotélico: o appetitus societatis do homem o impele para a constituição do Estado. O autor não aceita a idéia de um estado de natureza em que os homens vivessem more bestiarum, nem lhe agrada explicar a criação da vida social pela degeneração das qualidades humanas e a consequente necessidade de remediar essa indigência. Suárez não pensa como Hobbes. Antes da formação das comunidades políticas, houve uma situação transitória em que existiam apenas famílias. Contudo, mesmo que o homem não houvesse conhecido o pecado, as sociedades familiares deveriam integrar-se em agrupamentos políticos perfeitos. Exceção feita ao poder de coação, o Estado não representa um remédio para a natureza corrupta do homem, um processo a que este tenha recorrido para se defender dos perigos do primitivo estado de natureza, mas sim um estado eminentemente natural, que convém ao homem em quaisquer circunstâncias e é uma condição imprescindível de sua perfectibilidade ${ }^{24}$.

Esta concepção da autoridade política e da lei como necessidades naturais do homem constitui uma afronta às ideias políticas dos reformadores. Para escritores protestantes, havia um verdadeiro hiato entre Deus e o homem. Nessa lacuna, não existiriam institutos humanos, os quais seriam capazes de fornecer um fundamento racional para a moralidade humana. Somente a fé poderia cruzar o abismo entre Deus e a humanidade. Suárez, por sua vez, comunga de uma visão mais otimista. O Deus suareziano está mais próximo. A vida social e a autoridade política não correspondem a meios para compensar a degeneração; ao contrário, são um passo na caminhada para a realização humana. O pecado original apenas dificulta alcançar a perfeição neste e em outros aspectos da existência moral, mas

\footnotetext{
${ }^{23}$ Cf. DL. III, 1, 12.

${ }^{24}$ Cf. MERÊA, Paulo. Suárez, Jurista. Op. Cit., p. 134.
} 
não impossibilita ${ }^{25}$. Mesmo no De Legibus, antes de se inserir na polêmica, Suárez expõe uma teoria que, cedo ou tarde, iria sofrer repúdio pelos reformadores.

Ao demonstrar que o Estado consiste num preceito natural, Suárez consegue responder parte da pergunta inicial "se os homens possuem poder de mando sobre outros homens?". Por ser de direito natural, essa prerrogativa é legítima. Resta ainda investigar como se constituiu esse poder; em outras palavras, resta saber quem deve mandar e quem deve obedecer. Ainda que os escolásticos não acreditassem numa igualdade de fato entre os homens, em vista da igual paternidade divina, tampouco aceitavam alguma desigualdade substancial. Não se trata propriamente de uma igualdade jurídica, mas teológica. Mesmo assim, em face dessa igualdade, revela-se perturbador constatar que determinados homens mandam, e outros obedecem.

Mostrar a necessidade do Estado não equivale a afirmar a sua criação. Nem sempre as necessidades são satisfeitas. É aqui que Suárez se afasta da tradição. Embora a família constitua a base indispensável da comunidade política, esta não representa um alargamento ou uma derivação daquela. $\mathrm{O}$ autor repele a teoria do patriarcado: o poder do pai difere, em essência, não apenas no número de pessoas que devem obediência, do poder do príncipe. Mesmo Adão, o primeiro homem, possuiu apenas o poder doméstico, não o político ${ }^{26}$.

A natureza pode impelir o homem para a criação do Estado, mas a causa imediata deste reside no próprio homem: a sua vontade. Os homens devem reunir-se e celebrar um pacto. Embora com colorações bastante diversas, em Suárez, já há uma doutrina do contrato social: "de outro modo, pois, pode

25 Cf. HAAKONSSEN, Knud. Natural Law and Moral Philosophy: from Grotius to the Scottish Enlightenment. New York: Cambridge University Press, 1996, pp. 18-25.

${ }^{26}$ Cf. DL. III, 2, 3. ser considerada a multidão humana: por uma vontade específica ou um consentimento geral, ela se congrega num corpo político". Ou ainda: "Por esta razão, disse anteriormente que o poder do rei se funda num contrato ou quasi contrato" 27 (grifo nosso). A palavra "pacto" permeia todo o livro III do De Legibus, bem como a Defensio Fidei.

Apesar das referências expressas ao termo, o contratualismo suareziano guarda profundas diferenças com o dos contratualistas ingleses. Na concepção de Suárez, a liberdade dos homens não é um ato ex nihilo, mas uma deliberação racional que aperfeiçoa uma pulsão natural. A vontade humana constitui a causa imediata para o poder político, mas a decisão não é tomada sem a intervenção de qualquer a priori. Não há uma anarquia moral que precisa de uma redenção puramente da vontade humana. Em Suárez, a razão humana ratifica o impulso de verdadeiras estruturas morais naturais que impele o ser humano para o Estado. O homem no estado pré-político não é considerado em abstrato, desenraizado de um contexto social. Por esse motivo, Heinrich Rommen (1897-1967) prefere o termo consensus em vez de um acordo ${ }^{28}$. O Estado resulta da colaboração entre a natureza e a liberdade.

A jusfilósofa Teresa Rinaldi salienta que, em Francisco de Vitória (1483-1546), já existia

27 "Alio ergo modo consideranda est hominum multitudo, quatenus speciali voluntate, seu communi consensu in unum corpus politicum congregatur" (DL. III, 2, 4) e "Et ideo supra dixi potestatem regiam fundari in contractu vel quasi contractu" (R. P. Francisci Suarez. Granatensis è Societate Jesu, Doctoriis Eximi. Defensio Fidei Catholicae et Apostolicae adversus Anglicanae sectae errores, cum responsione ad Apologiam pro Iuramento Fidelitatis et Praefationem Monitoriam Serenissimi Iacobi Angliae Regis. Conimbricae: Didacum Gomez de Loureyro, 1613 [doravante DF], Livro III, capítulo 2, item 20).

28 Cf. ROMMEN, Heinrich. La Teoria del Estado y de la Comunidad Internacional en Francisco Suárez. Tradução para o espanhol de Valentin Garcia Yebra. Buenos Aires; Madrid: Facultad de Derecho y Ciencias Sociales y Instituto de Derecho Internacional; Instituto Francisco de Vitória y Consejo Superior de Investigaciones Cientificas, 1951, p. 114. 
a ideia de que o poder político seria formado pelo consenso dos homens. Mas o consenso nos dois autores difere ${ }^{29}$. Falta a Vitória a dimensão voluntarista de Suárez. Naquele, o consenso é uma consequência natural da vida comunitária. O poder civil constitui-se de maneira consuetudinária, não mediante um liame formal expresso num ato único, mas todos os dias, por meio de pequenas resignações. Em Suárez, a autoridade provém da natureza, mas a sua instituição do engenho humano. Em Vitória, tanto a autoridade em si mesma como a sua instituição possuem um fundamento natural.

\section{V - A Origem Popular da Soberania}

Todavia, para que um contrato social possa fundar a autoridade do soberano, deve pressupor-se a origem popular do poder, não a divina. O teólogo granadino precisa, portanto, contornar a famosa afirmação de São Paulo, na Epístola aos Romanos (XIII,1): "não há autoridade que não provenha de Deus (non est enim potestas nisi a Deo)". A origem divina do poder representava um axioma comum e em si mesmo indiscutível. Mas a afirmativa do apóstolo respondia apenas à origem do poder em termos abstratos; já em concreto, impunha-se determinar como o poder foi transmitido aos chefes seculares. Cabe sublinhar que, no quadro da cultura cristã, delimitavam-se duas hipóteses: ou o poder seria transmitido diretamente por Deus ao soberano - como se lê na Bíblia no caso de Saul e de Davi -, ou por meio de um mediador.

Jaime I defendia a primeira possibilidade, pois o retirava da subordinação tanto temporal como espiritual do papa. Suárez aceita a transmissão imediata do poder de Saul e

${ }^{29}$ RINALDI, Teresa. Origine e finalità della società politica nel De Legibus di Francisco Suárez. RIFD Rivista Internazionale di Filosofia del Diritto. Giuffrè, aprile/giugno 2001, n. 2, serie V, anno LXXVIII, p. 194.
Davi, mas considera este um caso extraordinário e sobrenatural. Normalmente, Deus age atrás da natureza: "segundo a providência geral e ordinária, não se transmite desse modo, porque os homens, consoante a ordem da natureza nas coisas civis, não se regem por revelações, mas pela razão natural". Na Defensio Fidei, Suárez chega até mesmo a questionar a validade desta transmissão em tela, pois advoga que Deus teria somente escolhido a pessoa para rei, mas a eleição coube ao povo ${ }^{30}$.

Uma vez excluída a primeira possibilidade, resta a da mediação. Como um bom homem religioso, Suárez aceita a validade da frase de São Paulo. Todo o poder, em abstrato, provém de Deus, mas Ele o conferiu posteriormente aos homens. E há duas maneiras pelas quais isso pode acontecer, o que acaba por gerar dois mediadores. "Primeiro, [Deus] confere um poder que, por essência, está necessariamente unido à natureza da coisa, a qual foi criada pelo mesmo Deus". Aqui, o poder decorre da própria coisa, e Deus apresenta-se como o primeiro titular desse poder na medida em que criou a coisa. Deus dá imediatamente o poder não por uma ação especial, mas como autor da natureza. É o caso da autoridade do pai sobre o filho: a cessão deste poder ocorre com a paternidade. A outorga do poder e a criação da coisa originam-se de um só ato. "No outro modo, Deus confere imediatamente por si mesmo (por assim dizer) e mediante uma doação especial, um poder que não está necessariamente vinculado à criação de um ser, mas Deus o confere, de forma tanto livre como aditiva, a uma natureza ou pessoa" ${ }^{\prime 1}$. Trata-se de uma outorga di-

30 "(...) iuxta communem autem, et ordinariam providentiam non ita sit, quia homines iuxta naturae ordinem non revelationibus, sed naturali ratione regulatur in his, quae civilia sunt" (DL. III, 4, 2). Cf. DF. III, 3, 5-10.

31 "Unus modus est dando potestatem, ut ex natura rei necessario connexam cum aliqua natura quam Deus ipse condit" e "Alio modo datur a Deo immediate potestas per se (ut ita dicam) et peculiari donatione, non ut necessario connexa cum alicuius rei creatione, sed ut voluntarie a Deo superaddita alicui naturae vel personae." (DF. III, 2, 3). 
reta que Deus realiza para além natureza. Foi o que ocorreu quando Jesus Cristo confiou o governo da Igreja a São Pedro. Na primeira forma, o poder procede do direito natural; na segunda, do direito divino positivo.

Portanto, os dois mediadores possíveis seriam o papa e a própria comunidade. A seguir, ver-se-á os motivos pelos quais Suárez exclui o sucessor de Pedro dessa qualidade. Para o autor, a autoridade política foi conferida por Deus aos homens no próprio momento da criação. Esta consiste na transferência primeira, os homens podem fazer o que desejarem desse poder depois. Porém, este poder não reside em cada homem individualmente considerado. Deus não concedeu a autoridade a nenhum homem em particular, nem a fracionou e distribuiu para cada ser humano. A autoridade só surge quando os homens se reúnem, não como uma simples multidão inorgânica, sem qualquer ordem ou laços físicos e morais, mas de outro modo, pois, pode ser considerada a multidão humana: por uma vontade específica ou um consentimento geral, ela se congrega num corpo político com um vínculo de sociedade e para ajudar-se mutuamente com vistas a um fim político, da mesma maneira que formam um corpo místico que moralmente pode chamar-se uno por sua natureza; este corpo, em consequência, tem necessidade de uma cabeça ${ }^{32}$.

Somente quando os homens se agrupam de maneira ordenada, com propósitos (políticos) definidos, surge a autoridade como um predicado natural. $\mathrm{O}$ corpo místico consiste num verdadeiro organismo, não biológico, mas moral. Trata-se de um todo distinto da soma de suas partes, porque é qualificado pela autoridade. E, para conseguir os fins propostos, ele necessita de uma cabeça. Suposta,

\footnotetext{
32 "Alio ergo modo consideranda est hominum multitudo, quatenus speciali voluntate, seu communi consensu in unum corpus politicum congregatur uno societatis vinculo, et ut mutuo seiuvent in ordine ad unum finem politicum, quomodo efficiunt unum corpus mysticum, quod moraliter dici potest per se unum: illudque consequenter indiget uno capite." (DL. III, 2, 4).
}

da parte de um grupo de homens, a vontade de se reunir em sociedade, a sujeição a um poder político consiste num corolário natural.

A natureza, porém, pressupõe o concurso das vontades humanas. E é então que neste corpo místico vai ocorrer o pacto. Uma vez que a liberdade natural constitui um preceito de direito natural dominativo, ela pode ser alienada pelos homens para um ou mais indivíduos. Suárez retoma a tradicional tripartição das formas de governo em monarquia, aristocracia, e democracia, nas suas formas puras ou corrompidas, e as modalidades de governo misto. Embora ele prefira a monarquia, o direito natural não prescreve nenhum tipo em especial. A escolha vai depender do conteúdo do pacto; todas as formas de governo pertencem ao direito positivo ${ }^{33}$.

A única exceção é a democracia. Ela poderia existir sem qualquer instituição positiva, apenas como resultado da sociabilidade natural ${ }^{34}$. Entretanto, ela não representa um mandamento da natureza, somente uma permissão. $\mathrm{O}$ direito natural não obriga a comunidade a conservar o poder de que se acha investida; em face das circunstâncias históricas e culturais, outra orientação política pode tornar-se mais aconselhável. Por isso, os homens podem escolher a forma de governo que lhes convier. Mas, perceba-se que, à diferença da teoria política moderna, não são os indivíduos que alienam os seus direitos naturais a um soberano, mas a comunidade como um todo. A autoridade constitui um predicado natural da multidão organizada, não dos homens singulares.

Por causa do contrato, nenhum regime apresenta-se essencialmente mau. Em princípio, todos podem ser bons e úteis. Faz-se mister tão somente que o titular ou titulares do poder público tenham recebido este da comunidade $^{35}$. A legitimidade do soberano encon-

\footnotetext{
${ }^{33}$ Cf. DF. III, 2, 7.

${ }^{34}$ Cf. DF. III, 2, 8.

${ }^{35}$ Cf. DL. III, 4, 1-2.
} 
tra-se condicionada pelo que for disposto no acordo. Apesar de constituir um pacto de sujeição - o povo "aliena" de forma irrevogável o poder -, a comunidade pode inserir limites à autoridade do soberano. Assim, podem ou não existir constrangimentos até mesmo de direito positivo ao poder.

Cabe observar que, à época de Suárez, vigia uma doutrina jurídica de poder político segundo a qual este pertencia à pessoa (ou às pessoas) do soberano, não ao Estado em si. Trata-se da teoria do Estado-objeto. O pacto, pois, não corresponde propriamente a um justo título de formação do Estado, mas à pertença da autoridade política por parte de determinado homem ou homens. Não obstante, esta potestas não sofre a menor comparação com o domínio de direito privado. "Acrescente-se que o reino não é comparável com outros bens ou com a administração do dote, porque ele é como um ofício da qual é incumbida a mesma pessoa a quem é conferido, e sua razão de ser não é tanto esta pessoa, mas aqueles que devem ser governados" ${ }^{\prime 36}$. Suárez perfilha, portanto, de uma concepção já difundida na Antiguidade e que mereceu da Igreja um favorável acolhimento: regnum non est propter regem, sed rex propter regnum. Para o autor, este é um critério seguro para distinguir o tirano do verdadeiro rei. O simples fato de emanarem do poder soberano não torna as leis humanas legítimas e respeitáveis. Deve observar-se o seu valor intrínseco: a sua conformidade com o direito natural e o bem comum e com as condições do pacto ${ }^{37}$.

Além do contrato, existem outros títulos legítimos de poder político. A sucessão hereditária consiste num modo derivado, pois os sucessores recebem o poder do povo indiretamente. A guerra e a posterior conquista ter-

\footnotetext{
36 "Accedit, quod in hoc non est comparandum regnum cum aliis bonis, seu cum administratione dotis, quia regnum est veluti quodam officium, quod incumbit propriae personae, cui confertur, et non tam est propter ipsam, quam propter eos, qui regen di sunt" (DL. III, 9, 12).

${ }^{37}$ Cf. . MERÊA, Paulo. Suárez, Jurista. Op. Cit., p. 135.
}

ritorial também podem aumentar o tamanho de um Estado. No caso de uma guerra justa, o título revela-se legítimo ab initio; já quando se tratar de uma guerra injusta, pode ocorrer de o povo, com o passar do tempo, dar o seu consentimento e admitir a soberania do conquistador. Dessa maneira, a prescrição pode justificar a pretensão ao poder ${ }^{38}$.

Dessa feita, Suárez já pode responder a pergunta inicial (se os homens podem mandar em outros homens?) na íntegra. Trata-se de uma afirmativa, porque os próprios homens acordaram dessa maneira. A autoridade em abstrato encontra-se em Deus e, em concreto, no povo, que pode fazer dela o que bem entender.

\section{VI - A Doutrina do TiRANicídio}

A outra opção possível de mediador seria o Sumo Pontífice. São Pedro recebeu seu poder diretamente de Jesus Cristo, e os seus sucessores, ainda que eleitos por um conselho, também recebem a sua autoridade de Deus. $\mathrm{O}$ ato humano, a eleição, constitui a causa próxima para que Deus, a causa principal, outorgue o seu poder. Embora a Igreja em si mesma forme uma comunidade, o poder não foi transferido por Deus para ela como um todo, mas somente ao seu chefe ${ }^{39}$.

Porém, além de comandar a Igreja, poderia o papa governar todos os reinos, ou, ao menos, todos os reinos cristãos? Tratava-se de uma teoria muito difundida segundo a qual o papa conservaria o poder in habitu, e os príncipes cristãos reinariam como delegados desta autoridade central.

Suárez demonstra o seu realismo ao constatar que essa delegação nunca existiu, pois não poderia ser desfeita. Todavia, a opo-

\footnotetext{
${ }^{38}$ Cf. DL. III, 4, 3-4 e DF. III, 2, 20.

${ }^{39}$ Cf. DF. III, 3, 13.
} 
sição de Suárez é mais profunda. Esta tese só poderia ser válida se, no decreto de doação a São Pedro, Jesus Cristo desejasse abranger todos os reinos. E o teólogo granadino lembra que a promessa era que Deus daria "as chaves do reino dos céus", mas nada afirmou sobre as da terra. Ademais, o próprio Cristo sempre confirmou que o seu reino não era deste mundo. Portanto, a jurisdição do Pontífice restringe-se somente à Igreja ${ }^{40}$

Suárez concebe esta limitação à autoridade do Sumo Pontífice e, em consequência, de toda a Igreja, porque promove uma distinção bastante radical entre o poder temporal e o espiritual. Ao citar o papa Nicolau (810867), numa carta ao arcebispo Albino, o Doutor Exímio lembra que a "Santa Igreja de Deus não tem outra espada fora a espiritual". Conclui que, mesmo nos Estados cristãos, ainda que integrem um só corpo místico e espiritual da Igreja, em virtude do direito natural, em toda a comunidade da Igreja, não existe imediatamente uma suprema jurisdição temporal e universal sobre toda a Igreja, mas existem tantas supremas jurisdições temporais quantas forem as comunidades políticas que não formam parte de um reino ou de um Estado ${ }^{41}$.

Em toda a Defensio Fidei, Suárez ressalta, de maneira expressa, que o poder espiritual pertence ao papa, e o temporal aos príncipes. $\mathrm{O}$ autor havia abandonado a ideia dos dois gládios da Igreja e, já no início do século XVII, acentua a diferença entre a jurisdição temporal e a espiritual. Não se pode inferir disso que o jurista de Coimbra estivesse a advogar a separação entre Igreja e Estado, mas ele conhecia sim a diferença entre o domínio político, essencialmente humano e terreno, e o religioso, que se apresenta divino e sobrena-

\footnotetext{
${ }^{40}$ Cf. DF. III, 5, 14-15.

41 "Sancta Dei Ecclesia gladium non habet, nisi spiritualem" (DF. III, 8, 9) e "(...) ex vi iuris naturalis non est in tota communitate Ecclesia immediate uma suprema iurisdictio temporalis et universalis super totam Ecclesia, sed tot sunt iurisdictiones temporales supremae, quot sunt politicae communitates, quae non sunt membra unius regni seu reipublicae civilis" (DF. III, 5, 11).
}

tural. Embora a concepção de um Estado laico pareça ainda estranha a Suárez, por sua vez, a noção de secularismo lhe é familiar. Suárez revela-se tão consequente com a distinção entre os domínios temporal e espiritual que se cristãos se encontrarem sob o jugo de um príncipe pagão, desde que não seja um tirano, não poderiam rebelar-se ${ }^{42}$.

Ainda havia uma hipótese em que o papa pudesse exercer a jurisdição temporal sobre os reinos e os principados: se ele houvesse recebido do imperador. No primeiro caso, Suárez rechaça a ideia de um decreto de doação de direito divino positivo; agora, ele aborda um problema de direito humano positivo. Trata-se de uma variação da tese do monismo imperial segundo a qual o papa, não o imperador, exerceria a jurisdição sobre todos os cristãos. Para Suárez, não havia nada mais anacrônico.

Sucedeu-se que o mesmo Império Romano foi dividido em oriental e ocidental; ademais, o império ocidental (somente este ficou em poder dos cristãos, depois de o oriental ter sido conquistado pelos pagãos), ainda que se conserve, no que tange à sua dignidade, em uma só pessoa, a sua jurisdição foi repartida entre muitos príncipes e reis. $E$, embora alguns destes se encontrem submetidos ao imperador, os demais estão legitimamente isentos por direitos de prescrição, aos quais se acrescem, ao mesmo tempo, o consentimento dos povos, ou o título oriundo da guerra justa. Portanto, supomos agora que, além do imperador, há vários reis temporais completamente independentes de sua jurisdição, como são os reis de Espanha, França e Inglaterra ${ }^{43}$.

\footnotetext{
${ }^{42}$ Cf. DF. III, 4, 2.

43 "Accedit illum ipsum romanum imperium in orientale et occidentale fuisse divisum, et deinde occidentale imperium (quod solum in christianis permansit, orientali a paganis occupato), licet quoad dignitatem in una persona duret, quoad iurisdictionem in multos principes et reges divisum esse. Ex quibus licet aliqui sint imperatori suiecti, plures censentur legitime exempti, iure praescriptionis, accedente simul populorum consensu vel titulo iusti belli. Ac proinde praeter imperatorem plures esse reges temporales ab illus
} 
A concepção de império universal não fazia mais sentido à época de Suárez. Então, a doação do reino de Roma realizada pelo imperador Constantino ao Sumo Pontífice implica, no máximo, jurisdição sobre as cidades deste patrimônio, nunca sobre todos os cristãos ${ }^{44}$. Como observa Rommen, a ideia de unitarismo imperial sob a pessoa do papa encerrava em si mesma os gérmenes de sua destruição. Ao subtrair da figura do imperador tanto a sua independência última do papado como a sua legitimação divina face aos príncipes territoriais, perdeu ele a sua influência política. E, em tempos de Reforma, com a estruturação das igrejas nacionais, o título divino de legitimidade exclusivo do pontífice não mais convencia ${ }^{45}$.

Até o momento, Suárez não parece poder contraditar os interesses do rei da Inglaterra. A sua teoria, de um lado, prescreve o conformismo político, pois a transferência do poder do povo para o rei consiste num pacto de sujeição: houve uma verdadeira alienação. De outro, Suárez retira o poder temporal do papa, a única figura que poderia opor-se às pretensões do monarca inglês.

Ademais, a conjuntura histórica e cultural que circundava o Doutor Exímio se mostrava pouco propícia para desenvolver teorias sobre a desobediência civil. Durante a segunda metade do século XVI - boa parte da vida de Suárez -, a guerra interna foi, nos países que passaram pela Reforma, em especial na França, o estado normal. Nessa época de atribulações religiosas e políticas, desenvolveu-se uma célebre literatura que fazia apologia aos direitos populares em detrimento do poder real, quando não legitimava a deposição ou, até mesmo, a execução do rei. Tratava-se dos "Monarcômanos", segundo a designação de seu adversário William Barclay. Em Espanha,

iurisdictione omnino líberos, ut sunt rex Hispaniae, Galliae et Angliae, nunc supponimus." (DF. III, 5, 7).

${ }^{44}$ Cf. DF. III, 5, 13.

${ }^{45}$ Cf. ROMMEN, Heinrich. Op. Cit., p. 394. contudo, as condições eram outras. O fundo conservador e crente da população, avigorado pelo Santo Ofício, punham o país a coberto das turbulências políticas. À acentuada fé católica do rei, respondia num coro uníssono os sentimentos da nação. Causa estranheza, pois, o fato de o jesuíta Juan de Mariana, pouco mais velho do que Suárez, de temperamento exaltado, formular no De Rege - o qual, parece ironia, é dedicado ao monarca - a doutrina do tiranicídio. Esta obra, como era de se esperar, não foi bem recebida, nem mesmo pelos seus colegas da Companhia de Jesus ${ }^{46}$. Mesmo assim, o Doutor Exímio a conhecia e, se ela não parecia válida ao contexto espanhol, poderia aplicar-se em outras paragens em que o soberano não fosse tão bem quisto.

A doutrina do tiranicídio, pois, não se tratava de uma novidade, mas parecia excêntrica ao pensamento suareziano. Contudo, mesmo sem abrir mão da diferença entre poder temporal e espiritual - ou talvez porque não abriu mão dessa distinção -, Suárez pôde introduzir esta concepção. Aquele que detém a autoridade soberana - "suprema" no original latino -, para o autor, implica a negação de qualquer outra autoridade humana superior. Esta não submissão pode ser absoluta, quando não reconhece nenhum poder mais alto tanto em matéria temporal como espiritual, ou relativa somente a questões temporais ${ }^{47}$. Esta última corresponde ao grau de soberania dos príncipes temporais, uma vez que o papa também exerceria uma soberania espiritual.

Pode ocorrer de um príncipe legislar em questões espirituais ou materiais conexas a questões espirituais. Neste caso, em virtude da soberania espiritual do papa (bem como da subordinação da felicidade temporal e política à espiritual e eterna), aquele soberano temporal encontra-se submetido, de modo in-

\footnotetext{
${ }^{46}$ Cf. MERÊA, Paulo. Suárez, Jurista. Op. Cit., pp. 120122.

${ }^{47}$ Cf. DF. III, 5, 1.
} 
direto, à autoridade pontifical ${ }^{48}$. Já começa a se delinear o contra-ataque a Jaime I; trata-se da teoria do poder indireto do Sumo Pontífice. E a prova da validade dessa tese revela tanto o realismo, como a coerência teológica de Suárez: se, ao papa, Deus houvesse conferido autoridade nas questões políticas, este poder seria imperfeito porquanto ineficaz, e nada imperfeito pode provir de Deus ${ }^{49}$.

E essa ingerência pontifical encontra-se muito bem delimitada. Não cabe ao arbítrio do Sumo Pontífice determinar os casos em que o soberano excedeu os limites de seu poder. As situações já são dadas a priori. Para explicar isso, Suárez distingue duas classes de tiranos: tirania quoad titulum e tirania quoad administratrionem. Na primeira forma, o tirano não corresponde propriamente ao soberano, pois usurpou o posto. No segundo modo, ainda que o príncipe ocupe o trono por justo título, ele reina de maneira tirânica. Isto, para Suárez, equivale a dizer que o soberano exerce o poder para benefício próprio em detrimento do bem comum: "[o tirano] oprime a seus súditos injustamente, espoliando, matando, pervertendo e perpetrando contra eles, em público, outras injustiças similares" ${ }^{\prime 50}$.

A tirania pode configurar-se primeiro por inobservância às condições estabelecidas no pacto - as quais eram chamadas de "lei régia", à época de Suárez. Mas estas ressalvas precisam constar de forma expressa. Segundo, por desrespeito ao direito natural, que persiste na comunidade perfeita. De modo diverso ao que ocorre com o contrato hobbesiano, os homens não alienam a sua faculdade de interpretação da lei natural. Revela-se sugestivo em Hobbes o fato de, no estado civil, as leis naturais permanecerem em vigor, mas

\footnotetext{
${ }^{48}$ Cf. DF. III, 5, 2.

49 Cf. SCOTT, J. B. The Catholic Conception of International Law. Washington D.C.: Georgetown University Press, 1934, p. 268.

50 “(...) subditos iniuste affligit, spoliando, occidendo, pervertendo vel alia similia publice et frequenter iniuste perpetrando" (DF. VI, 4, 1).
}

somente o soberano possui a competência para interpretá-las. O homicídio, por exemplo, continua proscrito, mas cabe ao soberano definir o homicídio ${ }^{51}$. Essa diferença ocorre porque o direito natural em Hobbes, e nos modernos de um modo geral, funda-se em sentimentos ou pulsões do próprio homem, ou baseia-se num fato da ordem do ser, não num dever ser. Em virtude da lei natural, em Suárez - embora desvelada pela razão humana - proceder da vontade divina, ela não pode ser invalidada por qualquer ato humano e possui um fundamento objetivo, o qual prescinde da interpretação humana para existir. Nenhum fato da ordem do ser, nem mesmo a razão, cria a lei, somente a vontade. E, no que tange ao direito natural, trata-se da vontade mais suprema.

Para lidar com a tirania, existem ainda diversos graus de desobediência civil anteriores ao regicídio. O jurista de Coimbra, em princípio, abomina qualquer forma de resistência a uma ordem do soberano. $\mathrm{O}$ autor revela-se um conformista. Se a injustiça do comando for leve, ele ainda aconselha o cumprimento em prol da ordem e do bem comum que seriam maculados com a insubordinação. No entanto, quando o próprio bem comum se encontrar em risco por causa de uma lei injusta, até mesmo se torna obrigatório a desobediência por parte dos súditos, pois não se trata de uma verdadeira lei ${ }^{52}$. Ainda assim, a ação do povo, até o momento, insere-se no plano da resistência passiva.

Tudo se torna diferente no caso de um usurpador. Suárez menciona a deposição de maneira explícita. Não é o rei de direito, é inimigo do reino e encontra-se virtualmente em guerra com ele. Qualquer membro do Estado

51 “O roubo, o assassínio e todas as injúrias são proibidos pela lei de natureza; mas o que há de se chamar roubo, assassínio, adultério ou injúria a um cidadão não se determinará pela lei natural, porém pela civil." (HOBBES, Thomas. Do Cidadão. Trad. Renato Janine Ribeiro. São Paulo: Martins Fontes, 2002, p. 112. Livro VI, 16).

${ }^{52}$ Cf. DL. III, 10, 7. 
- e até um estranho - pode defender a comunidade até a morte. Faz-se necessário apenas que não haja um superior a quem recorrer, que o título seja notoriamente injusto, que não haja outro meio menos extremo para libertar o Estado, que não haja pacto ou tréguas com o povo, que o regicídio não venha a provocar maiores males, e que o povo - reunido em sociedade perfeita - não se oponha de modo expresso ${ }^{53}$.

Não obstante, entre as duas modalidades de tirania, Suárez prefere abordar aquela que, apesar do justo título, tornou-se ilegítima por causa do exercício, pois ela se ajusta melhor ao caso do rei inglês. O raciocínio parece simples. Se a comunidade perfeita transferiu o poder ao rei, foi mediante a condição deste não governar tiranicamente; portanto, se ele se tornar um tirano, a comunidade poderia retomar a sua autoridade inicial de forma justa. Pelo princípio da legítima defesa, o Estado poderia, para a sua conservação, insurgir-se, derrubar o tirano e, até mesmo, se não houver outro jeito para a sua defesa, condená-lo à morte.

Todavia, o autor recorda que o Concílio de Constança condenou aqueles que atentam contra a vida do tirano por sua própria e privada autoridade. Cumpre ressaltar que este concílio ocorreu em 1415; ele antecede em mais de um século o Cisma. A condenação dirigia-se à doutrina proposta por John Wycliffe (1328-1384) e John Huss (1369-1415), segundo a qual os senhores do mundo perderiam o seu domínio automaticamente por qualquer pecado mortal e poderiam ser castigados pelos seus súditos. O Concílio em nada se relaciona com a Reforma protestante. Mas Suárez, como um bom teólogo, não pode afrontá-lo. De fato, nenhum homem pode tirar a vida de seu rei por vários motivos: primeiro, porque punir e rechaçar as injúrias são prerrogativas daquele a quem se confia o bem comum; segundo, porque o poder coercitivo pertence somente ao soberano; terceiro, porque este tipo

\footnotetext{
${ }^{53}$ Cf. DF. VI, 4, 7-11.
}

de ato provocaria tumulto dentro do Estado. Se um particular não pode matar outro particular, mesmo que este tenha cometido um crime, que dirá assassinar o rei, ainda que tirano ${ }^{54}$.

O problema resume-se à autoridade privada. Nenhum homem pode, por sua própria autoridade assassinar o tirano, pois o poder reside no povo, reunido num corpo místico, não nos homens individuais. Quando o rei se torna um tirano, o poder retorna à comunidade, não aos indivíduos isolados. Dessa feita, o corpo moral precisa constituir-se novamente, e a sentença ao tirano deve provir não de um indivíduo, mas de um conselho público de todas as cidades e procuradores. Neste instante, pode recorrer-se ao papa. O Estado pode reunir-se nesta espécie de assembleia pública sempre que as necessidades de sua conservação se impuserem. Mas, no caso especial de leis injustas sobre matérias espirituais ou conexas, a autoridade do Sumo Pontífice pode e deve ser ouvida ${ }^{55}$. Trata-se da substituição de uma autoridade pública (a comunidade) por outra (o papa).

Suárez, entretanto, não chega ao extremo de aplaudir a atitude de Sêneca que, sob as ordens do imperador tirano, aceita se matar. A proibição ao regicídio não impede a legítima defesa. O súdito, porém, não pode recorrer à violência se o valor em perigo for um bem material. Só a defesa da vida justifica a morte do tirano. Porque "o direito a proteger a própria vida está acima de tudo e, neste momento, a necessidade que move o soberano não é tão imperiosa a ponto de obrigar o súdito a sacrificar sua vida por ele; ao contrário, em vez disso, o soberano coloca-se ele mesmo em situação de risco" ${ }^{\prime \prime}$.

\footnotetext{
${ }^{54}$ Cf. DF. VI, 4, 3-4.

${ }^{55}$ Cf. DF. VI, 4, 15.

56 “(...) ius tuendae vitae est maximum, et tunc princeps non est in necessitate, quae obliget subditum ad vitam pro illo perdendam, sed ipse voluntarie et inique in illo discrimine constituit" (DF. VI, 4, 5).
} 
Mesmo que o pacto preveja a sujeição absoluta dos súditos, sem qualquer reserva, inclusive sobre o direito à vida, Suárez admite a legítima defesa individual. Cumpre salientar que, à época do autor, os castigos corporais e a pena de morte representavam expedientes corriqueiros e eram considerados legítimos. Deve sublinhar-se, portanto, que Suárez não está advogando a abolição da pena de morte. A explicação possível reside no próprio pacto: ele foi estabelecido pela comunidade como um todo, reunida num corpo moral, não por cada indivíduo. A comunidade, conforme as circunstâncias culturais e históricas, decide aceitar ou não a aflição de castigos corporais e da pena de morte para manter a paz interna (o que constitui um requisito para o bem comum). Se houver reservas a isso, elas devem constar de forma expressa no pacto. Todavia, mesmo na ausência delas, foi a comunidade, não cada pessoa, que acordou a pena de morte. Mas uma pessoa em particular, destacada da convivência comunal, possui o direito a defender sua vida.

$\mathrm{O}$ direito à legítima defesa revela-se a única exceção que alguém, movido por autoridade própria e privada, pode assassinar o rei. Ainda assim, Suárez adverte que este caso não deve estender-se a todas as situações, sempre. Se a morte do soberano trouxer à sociedade tamanhos distúrbios que possam lesionar o bem comum, o amor à pátria deve impedir o indivíduo de matar o príncipe, ainda que isso ponha a sua vida em risco. $\mathrm{O}$ teólogo granadino lembra, contudo, que esta obrigação foge ao escopo do Direito e se insere na ordem da caridade ${ }^{57}$.

Assim, a desobediência civil - e o tiranicídio, na sua forma mais extrema - apresenta-se possível somente porque, apesar do pacto consistir numa alienação, o primeiro titular é o povo, e há formas deste reaver o seu poder original.

\section{VII - ConCLusÃo}

Indubitavelmente, Suárez encontrava-se imerso na cultura católica, ibérica, aristotélica e tomista. Entretanto, esta tradição não era uma camisa de força e lhe permitiu lidar com as questões do seu tempo: a Reforma, a legitimidade do poder do Estado, o direito popular de resistência política, o direito internacional e o realismo político e o cinismo de um Maquiavel. Ao escrever no início do século XVII, Suárez consegue abraçar toda a tradição política medieval. Mas os problemas do seu tempo já eram outros.

Ele viveu um período de transição de um mundo medieval e teocêntrico para outro moderno e secular; viu o desenrolar das últimas guerras de religião para um sistema internacional baseado na raison d'état e no equilíbrio do poder; sentiu o anacronismo das justificativas nostálgicas sobre o poder difuso da Respublica Christiana em descompasso com a consolidação dos Estados nacionais. Suárez é, portanto, um homem de transição.

Mas Suárez não é só isso. Ele possui a originalidade dos liberais britânicos e a sutileza dos escolásticos; e essa combinação gera um diferente tipo de pensamento. Ele não se limitou a repetir o velho e a delinear o novo. $O$ velho e o novo são combinados de modo a formar um sistema coerente de ideias em que se pode extrair o melhor dos dois mundos. As principais características do liberalismo clássico são os direitos naturais, o contrato social e os limites para o poder do Estado. Todos estes elementos podem ser encontrados na Defensio Fidei e no De Legibus. Francisco Suárez é o mais hispânico entre os pais do liberalismo. cos

\footnotetext{
${ }^{57}$ Cf. DF. VI, 4, 5.
} 